\title{
INTERCULTURAL MARRIAGES: CURRENT TRENDS IN THE REPUBLIC OF NORTH MACEDONIA
}

\begin{abstract}
Families and married couples in modern societies are constantly facing changes and adjustments to the influence of the processes of urbanization, globalization, individualization, and continuous technological development. Additionally, as a result of the increased geographical mobility of the population in the last century, contemporary societies are mostly ethnically or racially heterogeneous. In the 21st century, intercultural marriages, i.e. partnerships between individuals of different ethnic or racial backgrounds, are becoming more common in the world and are attracting the attention of sociological and psychological research.

The Republic of North Macedonia is a multiethnic and multi-confessional country, however, it does not have a high rate of intercultural marriages, since they are not entirely socially accepted. In this paper, we will analyze intercultural marriages - known colloquially also as mixed marriages - in the world and in the Macedonian multicultural society. We will analyze the complexity of intermarriage from a theoretical point of view and examine relevant research on this topic. Additionally, we will present the data from qualitative research on intercultural marriages in North Macedonia, which was conducted during 2020 and refers to the experiences of married couples from intermarriage.
\end{abstract}

Key words: intercultural marriages, mixed marriages, Republic of North Macedonia.

\section{Introduction}

Since the beginning of the 20th century, modern marriage has been defined as a union of two partners based on a romantic relationship. The main debates about modern marriages concern gender roles within marriage, the importance of sexual relations and their nature, the degree of individual freedom of partners, the division of domestic labor, ethnically and racially mixed marriages, etc.

In modern societies, as a result of the processes of urbanization, globalization, individualization, and continuous technological development, family life and married couples are continuously facing changes and adjustments. Moreover, due to the increased geographical mobility of the population, many contemporary societies are mostly ethnic and racially heterogeneous, and consequently, there is a general growth of intercultural marriages. In Macedonian 
society, however, intercultural marriages are not fully socially accepted, although North Macedonia is a multiethnic and multi-confessional state.

This paper focuses on intercultural marriages, i.e. families in which the partners are from a different ethnic or religious group, known colloquially as mixed marriages. In this paper, we will give a brief overview of the current situation in the world and in our multicultural society and we will analyze the complexity of mixed marriages. Additionally, we will present the data from qualitative research on intercultural marriages in North Macedonia which was conducted during 2020. The research aims to present the experiences of married couples from intermarriage, the dynamics of their partnership, the reactions of family, friends, and the community to the choice of their partner, as well as dynamics of married life in North Macedonia.

\section{Intercultural marriage in the world: concept and trends}

In the past, the main social function of marriage was sexual relations regulation, reproduction, and inheritance. In fact, over the centuries, marriage has maintained class-based endogamy, that is, the establishment of marital relations within a group, usually in order to regulate inheritance and social status. Formerly, social class endogamy included the circulation of property and wealth among a limited circle of people, as well as marriage between relatives - a strategy of merging property, which would otherwise be divided among numerous heirs. Endogamous marriage practices of various types were common in the Western World until the 20th century. Today, social stratification is still present in this manner perhaps only in India, where arranged marriages are practiced within the same caste or social stratum. According to Elizabeth Abbott, the principles of endogamous marital practice can be divided as: (1) religious prohibition against marrying a member of another faith; (2) endogamy on the basis of national-ethnicity (avoiding marrying members of another nationality, or ethnic group); (3) racial endogamy and (4) professional endogamy (Abbott, 2014). In our paper, we will focus mainly on exogamy on the basis of nationality and ethnicity and we will partially analyze racial exogamy.

In the 21st century, the number of intercultural marriages is growing and attracting the attention of sociological and psychological research. Among other things, intercultural marriages are an important indicator of relationships quality between different groups in society (Smits, 2010, p. 418), and that is the main reason they are the subject of research in multicultural societies. However, despite the increasing contact of people of different racial, ethnic, or religious backgrounds from the 1960s to the present, there are insufficient accurate quantitative studies on certain matters related to the process of assimilation of individuals within a partnership or marriage, the degree of social distance between racial, religious and ethnic groups, as well as the internal cohesion among partners' individual group. Most often, the research refers to the socio-psychological characteristics of these partnerships or marriages and the problems faced by 
partners and children (Danika, Hiew, Kim and Shuang, 2014, pp. 87-88). Additionally, the dominant literature on racially mixed marriages is from the United States of America, a multicultural country known as the 'melting pot' due to its racially and ethnically mixed population. Finally, studies related to intercultural marriages are usually micro-studies or research related to the analysis of partnerships of two different ethnic groups, two races, or intercultural marriages in one country or region.

Historically, intercultural marriages have been rare and often subject to disapproval by parents or the community. In the United States, for instance, there was a legal ban on intermarriage until 1967. Although some degree of disapproval and discrimination in these marriages and relationships still exists today (in Malaysia there is still a ban on intercultural marriages), in most parts of the world the situation has changed and social barriers and prejudices have been reduced. In the United States, intercultural marriages grew by 1,000 percent from the 1960s to the beginning of the 21st century, and according to a 2002 survey, the majority of Americans embrace these relationships and marriages. There is an increase in intercultural marriages in other parts of the world as well: Europe (mostly in France), East and Southeast Asia (mostly Japan, South Korea, and Singapore), Australia and New Zealand (Danika, Hiew, Kim and Shuang, 2014, p. 88).

Milton L. Baron and Joseph Golden, two American theorists from the 20th century, believe that the decision to abolish racial segregation in schools in the United States has significantly increased the number of racially mixed marriages. Golden confirms this indirectly and considers that propinquity or closeness is a random factor in the decision to enter into an intercultural marriage. Barron, on the other hand, argues that marital and couples research suggests that young people are generally prone to marry because of economic and residential proximity, professional similarities, similar experiences, contacts, and education. Therefore, mixing young people of different races in schools, in the long run, should increase the rate of intercultural marriages. In addition, this theory confirms the fact that many married couples in the United States meet in college, away from home, where peer pressure and parental and community influence in choosing a partner is diminished (Aldridge, 1978, pp. 355-357).

As for the European continent is concerned, the situation is more complex. Firstly, in Europe, we study ethnically mixed marriages, unlike the racially mixed marriages that are characteristic of American society. Furthermore, each European country has its own unique immigration history and we cannot determine general trends of intercultural marriages. In addition, many countries in Europe in the recent decades have noted a growth in foreign populations and ethnic minorities as a result of the high rate of immigrants coming outside Europe and the European Union, as well as the increased geographical mobility of the population within the EU. Therefore, besides the origin and number of immigrants, the experiences of immigrants are different from country to country, as well as the degree of their assimilation and integration into the new societies. 
There are several studies that analyze the differences in the behavior of demographic groups in Europe, namely immigrant groups and domestic population, separately and comparatively. According to them, the high rate of intercultural marriages in European countries is interpreted as an indicator of general mutual acceptance between immigrants and the domestic population. If we take into account the fact that individuals generally choose a partner with similar socio-cultural characteristics, the high number of exogamous marriages (in this case marriages between the domestic population and immigrants) is an additional indicator of successful integration of foreigners or a minority group. Conversely, the high rate of intercultural marriages may be due to the low cultural and socio-economic distance between certain groups of immigrants and the domestic population. Such examples exist in neighboring countries that share close historical, social, and economic ties and in which the rate of migration from one country to another is high (Hannemann et al., 2018, pp. 488-489), such as among former Yugoslav republics.

According to a comparative study of ethnic endogamy (more specifically first marriage within the same or different ethnic group among the migrant population) conducted in seven European countries (United Kingdom, France, Romania, Switzerland, Estonia, Belgium, and Spain) of men and women born between 1950 and 1989, based on official statistics from each country in the period from 1994 to 2013 (a different year for each country), certain trends in intercultural marriage in Europe emerged. According to the general conclusions of the research, in all seven countries, there is a prevalence of first marriage within the same ethnic group, especially when it comes to marriage between persons belonging to immigrant groups outside the EU. In five out of seven countries, there has been a change in attitudes towards marriage between the first and second generation of immigrants. Immigrants outside the EU, such as Pakistanis in the United Kingdom, Turks in Belgium and France, etc., are showing more conservative marital trends. These results indicate the importance of cultural heritage in family decision-making when it comes to choosing a spouse. The reason for the lower number of intercultural marriages in these cases can be related to the degree of adaptation in the new country through which the parents or the first generation of immigrants has passed. In general, it is expected that the second generation of immigrants will accept the marital norms of the domestic dominant population if the parents had a high degree of assimilation in the new country. This, in turn, may be the result of a high degree of mutual acceptance of both groups, that of immigrants and the domestic population. Furthermore, children of ethnically mixed parents are more likely to choose a partner who belongs to the domestic population (Hannemann et al., 2018).

In addition to these general conclusions, the research draws specific marital trends in individual countries or ethnic groups. For instance, Switzerland has a high rate of intercultural marriages between ethnic groups from neighboring Western European countries. This result is expected in the Swiss context, given that these groups are already accepted in society. Also, Turkish 
immigrants showed similar marital trends (low exogamy rates) in three different countries: France, Belgium, and Switzerland. Conversely, a low rate of endogamy was shown by expatriates from Western Europe whose temporary or permanent mobility across EU countries has increased significantly in recent decades (Hannemann et al., 2018).

Even though the results of this research on intercultural marriage in seven European countries provide new data and general conclusions, it, however, confirms that in Europe we cannot talk about common trends of ethnically mixed marriages. As mentioned above, the history of each country is different, as are the cultural and socio-economic ties between the different peoples living in one country. That is why, most often, the studies on intercultural marriages focus on one country or follow the marriage trends of certain ethnic groups.

\section{Intercultural marriages in North Macedonia: the Yugoslav past and the current situation}

Studying intercultural marriages in North Macedonia is a challenge, primarily due to the fact that the number of quantitative studies and official statistics on their number is limited. Additionally, multiethnic families, i.e. families in which the partners are from a different ethnic or religious group, are not fully accepted in the Macedonian contemporary society, although it is a multicultural and multi-confessional state. Intercultural or mixed marriages are least accepted among ethnic groups of different faiths, between the Muslim and Christian populations.

In order to understand the social context in which various ethnic groups in North Macedonia and the Balkan Peninsula live today, we need to analyze the historical, economic, and socio-cultural ties between them. Namely, during the Ottoman period in the Balkans, religious affiliation was the most relevant feature of self-determination, more important than national and ethnic ones. Although Muslims had dominance and control over the non-Muslim population, Christians had limited religious freedom, especially in the Orthodox Rum millet. The territory of geographical Macedonia was probably one of the most problematic and "the most complex ethno-linguistic regions left to the Ottoman Empire after the Treaty of Berlin in 1878" (Magosci, 1995, p. 87), and even today North Macedonia remains deeply divided into ethnic or religious lines. Religion and language remained the main determinants of the self-determination of ethnic identity on the Balkan Peninsula until the interwar period.

During the Yugoslav period, on the other hand, secular ideas began to spread in the Socialist Republic of Macedonia and the new socialist-egalitarian spirit and the ideals for the liberation of religious consciousness were characteristic of the post-war Macedonian society. Data from some studies of the circumstances in Yugoslavia show a relatively high rate of ethnically mixed marriages from the 1960s until its break-up when it reached 13\% of the total number of marriages between 1987 and 1989. By comparison, in the United States, during 
the same period in 1994, only $2.4 \%$ of marriages were racially mixed. The reason for the high rate of ethnically mixed marriages in the former Yugoslavia, according to some authors, is primarily due to the successful integration of ethnic groups in Yugoslav society, but also due to the fact that some people identified as Yugoslavs, and in some censuses their number was higher than that of people who identified as Macedonians or Slavs (Somer, 2001, pp. 137-139).

Even though Yugoslavia is an example of a successful multicultural state in which there was interethnic coexistence and peace, relative economic, political, and social stability that lasted until the late 1980s, there were some ethnic tensions and demands for minority rights of certain groups (Somer, 2001, pp. 138-140). In fact, despite the spread of the ideals of brotherhood and unity and the high rate of intermarriage in Yugoslavia, one of the main causes of conflict after the break-up of the federation was religious and ethnic intolerance between nations, including the military conflict between Orthodox Macedonians and Muslim Albanians in Macedonia in 2001.

The theory of social cohesion, according to which, intercultural marriages reduce the likelihood of violent conflict between different social groups, is used in another study of mixed marriages in the former Yugoslavia. According to the author, Smits, the rate of intercultural marriages in Yugoslavia was not de facto very high (Smits, 2010; Botev, 1994). He argues that the number of mixed marriages between ethnic groups with the same (or similar) language and/or religion was much higher (e.g. between Serbs and Montenegrins) than between ethnic groups that did not share language and particularly religion (for example between Slovenes and Albanians), which confirms the fact that the number of mixed marriages between Muslims and Christians was still minor.

The rate of ethnically mixed marriages in Socialist Macedonia was relatively high and it amounted to 10\%. It was the highest in the period 1962-1964 when it was $13.5 \%$ of the total number of marriages, and then gradually began to decrease and was: 9.9\% (1970-1972), 8.2\% (1980-1982), while before the breakup of Yugoslavia (1987-1989) it was 7.8\% (Somer, 2001, pp. 137-139). Intercultural marriages in Socialist Macedonia, as well as in the other Yugoslav republics, were generally between ethnic groups that shared territorial or linguistic proximity or belonged to the same religious group, namely Turks and Albanians, Macedonians and Serbs (Stojanoski, 1995).

Regarding the current situation of intercultural marriages in North Macedonia, the data indicate that the rate of mixed marriages is even lower than in the period before the independence of the country and averages about $7 \%$. Namely, according to the latest available statistical data of the State Statistical Office from 2019, Macedonians entered into most marriages (151) with Serbs, there were 55 marriages with Albanians, 23 marriages between Macedonians and Turks, 17 with Roma, 12 with Vlachs, and the least (7) with partners from the Bosniak ethnic community. Albanians contracted most marriages (55) with Macedonians, 46 entered marriage with Turks, 25 with Bosniaks, four marriages 
were contracted with partners from the Roma and Serbian community and only one marriage is between Albanians and Vlachs.

Table 1:

Marriages by ethnicity of the bride and groom (2019)

\begin{tabular}{|c|c|c|c|c|c|c|c|c|c|c|}
\hline & $\begin{array}{l}\text { Groom } \\
\text { total }\end{array}$ & $\begin{array}{l}\text { Mace- } \\
\text { doni- } \\
\text { an }\end{array}$ & $\begin{array}{l}\text { Alba- } \\
\text { nian }\end{array}$ & $\begin{array}{l}\text { Turk- } \\
\text { ish }\end{array}$ & Roma & Vlach & $\begin{array}{l}\text { Ser- } \\
\text { bian }\end{array}$ & $\begin{array}{l}\text { Bos- } \\
\text { niak }\end{array}$ & $\begin{array}{l}\text { Oth- } \\
\text { er }\end{array}$ & $\begin{array}{l}\text { Un- } \\
\text { known }\end{array}$ \\
\hline $\begin{array}{l}\text { Bride } \\
\text { total }\end{array}$ & 13.814 & 7.157 & 4.892 & 490 & 499 & 14 & 71 & 101 & 276 & 314 \\
\hline $\begin{array}{l}\text { Mace- } \\
\text { donian }\end{array}$ & 7.037 & 6.842 & 17 & 16 & 10 & 9 & 52 & 5 & 68 & 18 \\
\hline $\begin{array}{l}\text { Alba- } \\
\text { nian }\end{array}$ & 4.841 & 38 & 4.741 & 31 & 2 & - & - & 9 & 18 & 2 \\
\hline $\begin{array}{l}\text { Turk- } \\
\text { ish }\end{array}$ & 461 & 7 & 15 & 428 & 4 & - & - & 3 & 4 & - \\
\hline Roma & 492 & 7 & 2 & - & 470 & 1 & 3 & - & 7 & 2 \\
\hline Vlach & 9 & 3 & 1 & - & - & 4 & 1 & - & - & - \\
\hline $\begin{array}{l}\text { Serbi- } \\
\text { an }\end{array}$ & 121 & 99 & 4 & 2 & 3 & - & 10 & 2 & 1 & - \\
\hline $\begin{array}{l}\text { Bos- } \\
\text { niak }\end{array}$ & 101 & 2 & 16 & 3 & 2 & - & 1 & 73 & 4 & - \\
\hline Other & 439 & 146 & 94 & 8 & 5 & - & 4 & 8 & 174 & - \\
\hline $\begin{array}{l}\text { Un- } \\
\text { known }\end{array}$ & 313 & 13 & 2 & 2 & 3 & - & - & 1 & - & 292 \\
\hline
\end{tabular}

Source: State Statistical Office of North Macedonia

The data presented in Table 1 gives a detailed overview of intercultural marriages contracted between brides and grooms of all ethnic groups and according to it, we can note that there are no major changes in the dynamics of marriages between different ethnic groups in North Macedonia. Specifically, most mixed marriages are contracted between ethnic groups that share the same religion (Macedonians-Serbs, Albanians-Turks), although the number of marriages between Macedonians and Albanians is not negligible, and it might indicate a greater degree of tolerance among these two ethnic groups. In fact, the level of acceptance and religious tolerance between different ethnic communities in recent years has relatively developed in Macedonian multicultural society. Namely, a study on mutual religious and ethnic tolerance among young people in North Macedonia from 2019, identified a low level of xenophobia and religious intolerance, but a certain degree of ethnic distance between different communities (Avirovic Bundalevska, Dragovic, 2020). However, despite the relatively successful coexistence between different ethnic groups in contemporary Macedonian society, the number of mixed marriages remains unchanged, which indicates that when choosing a spouse, in North Macedonia there is a 
certain level of endogamy based on religion or ethnicity i.e. avoiding marriage with members of another community.

\section{Research on intercultural marriages in North Macedonia}

In 2019, we conducted qualitative research on the perception of new models of families in contemporary Macedonian society by two different age groups. According to that study, conducted on 62 respondents from North Macedonia, mixed marriages were qualified as "complex", "subject to community condemnation", or with the possibility of "negatively affecting children". Additionally, the results of the research indicate that the majority of respondents in North Macedonia do not fully accept multiethnic families and mixed marriages, especially those between partners of a different faith (Avirovic Bundalevska, 2020). Stimulated by these results, we decided to conduct separate qualitative research of mixed married couples from North Macedonia, in order to better analyze their experience.

In the period from October to December 2020, we interviewed a total of 25 people, most precisely eight married couples and nine married spouses. The study was conducted using a structured questionnaire, online or by telephone due to the conditions imposed by the Covid-19 pandemic and people gathering restrictions. The questionnaire consists of nine questions with sub-questions with the possibility of free answers and discusses the setting and family in which the respondents grew up, how the partners met and the dynamics of their relationship, family, friends, and community reaction of their relationship and/or marriage, the wedding ceremony, marital life, children and the way they are brought up. The majority (15) respondents are aged 35 to 50 years, seven respondents are under 35 years old, two are over 50 years old and one respondent is 65 years old. We interviewed people from both rural and urban areas: 11 respondents are from Skopje and the surrounding area, two respondents from Tetovo, Kumanovo, and Debar and the surrounding area, one respondent from Gostivar and Kicevo and the surrounding area, while seven respondents are of foreign origin, five of which come from a Balkan country. In terms of gender representation, 11 respondents are male, while 14 respondents are female. Three of the respondents have completed primary education, while the remaining respondents have completed secondary (11) and higher education (11).

In the study, we define intercultural or mixed marriage in North Macedonia as a marriage in which the partners are of different ethnic origin, and in the analysis, we included as well foreigners (immigrants) married to Macedonian citizens. The majority of mixed marriages (five) were between members of the Albanian and Macedonian ethnic groups, the rest were marriages between Roma and Macedonians, Roma and Albanians, Albanians and Turks, Macedonians and Bosniaks, Macedonians and Turks and Macedonian citizens and foreigners. The main hypothesis of our research was that people who grew up in an ethnically mixed setting would be more likely to marry a person from 
a different ethnic group than those who grew up in a homogeneous ethnic environment. Furthermore, we assumed that people who grew up in a liberal family would be more likely to marry a person from a different ethnic group than those who grew up in a patriarchal family type. Another secondary hypothesis was that married couples from different ethnic groups but the same religion felt less family or community pressure than married couples of a different faith.

When it comes to their origin, the majority of respondents, especially those from urban areas, grew up in an ethnically mixed neighborhood, and two respondents grew up in ethnically mixed families. This fact confirms our main hypothesis as well as Golden's theory according to which proximity is a random factor in the decision to enter into intercultural marriage. Actually, one Macedonian respondent from the Skopje municipality of Chair pointed out that the environment in which he grew up and the school he attended enabled him to have close contact with people from different ethnic groups. "I had contact with Albanians and Turks in primary school because we lived in such a neighborhood "[...] my wife and I met in our second year of high school." However, from the individual conversations with the respondents, most often the future spouses did not actually meet in the same community in which they grew up, but at work, through mutual friends, at university, on summer vacation, etc., and there are also mixed marriages between respondents from ethnically homogeneous backgrounds, particularly in rural areas.

Besides community impact, we believe that the upbringing and the family in which the individuals grew up have a great influence in making the decision to marry a partner of different ethnic origins. That is why one of our assumptions was that people who grew up in a liberal family were more likely to marry a person from a different ethnic group than those who grew up in a patriarchal family. Our research has shown that this hypothesis is completely rejected, because all but two respondents, described their family as traditional or patriarchal. Although our assumption was completely incorrect, we believe that the results are due to the advanced age of the majority of respondents and that if we repeat the study on a younger group of respondents, we might get different results.

In addition, many respondents indicated that their families, in addition to being traditional and patriarchal, were also highly religious families. Therefore, the decision of some of the respondents to marry a partner of different faith was not approved and provoked a series of negative reactions from the parents. Namely, except for five respondents, all others indicated that they felt some pressure from friends, family, or the community after the choice of their romantic partner. Some respondents explained that the negative reactions by their families were only in the initial stage of the relationship or until the birth of their children, others defined it as intense, to the extent that the girl had to be a "runaway bride". Other respondents pointed out that their parents gave up on them publicly due to their choice of a romantic partner. Spouses belonging to different ethnic and religious groups felt the most stress, which confirms 
our secondary hypothesis that married couples who are from different ethnic groups but share the same religious background feel less pressure by family or community than those with a partner of a different faith. The analysis of this part of the research also showed that the most frequent negative reactions were by a male family member, most often by brother(s) or father of the respondents, particularly reported by the brides. Although the male respondents also indicated that their relationship or marriage was disapproved, we noticed a prevalence of negative reactions confirmed by the female respondents, which we believe is due to the fact that they mostly come from a patriarchal family type. As far as community prejudice is concerned, it is often described as gossiping or discouraging respondents about their choice of partner and warning that such marriage would not succeed due to major cultural or religious differences.

As for the wedding ceremony, we cannot make a general conclusion, although there is a prevalence of answers according to which two celebrations were held, in order to respect the wedding rituals of both cultures and families. In a minor number of cases (two), the respondents changed their faith to marry in a religious ceremony but indicated that they were not pressured by their partners to make such a decision. All married couples (except one who was expecting a child at the time of the survey and another couple who has no children) have children who are brought up in the spirit of the two ethnic or religious communities to which they belong. Furthermore, if the parents speak a different language, the children usually speak both languages, they celebrate the holidays of both cultures and are brought up to accept and rejoice differences. Only the respondents who changed their faith when marrying their partner pointed out that the children are brought up in the spirit of only one religious group.

Regarding the last question and the opinion of the respondents on mixed marriages in contemporary Macedonian society, we received divided answers with a prevalence of negative opinions. Our respondents consider that mixed marriages in North Macedonia are not fully accepted, particularly when it comes to rural and ethnically homogeneous environments and mixed marriages in which the partners are of a different faith. To this question, a respondent from Skopje answered that "[...] in this society, with low tolerance and prejudices, I think it is very difficult for them [mixed marriages] to be accepted at all". Unusual was the answer of three married couples according to which the partners have opposing views on this issue. Namely, one spouse believes that mixed marriages are accepted in North Macedonia, whilst the other considers that they are not fully accepted in Macedonian society. We believe that this result is due to the different experiences regarding family or community pressure of these respondents when choosing a spouse from a different ethnic group. This general conclusion is actually confirmed by the statistical data that indicate a small percentage of intercultural marriages in North Macedonia as well as the result of our previous research on the perception of multiethnic families and mixed marriages in North Macedonia, according to which there are still stere- 
otypes about these marriages in our society. Finally, our research confirms that in contemporary Macedonian society the first two principles of an endogamous marriage of Elizabeth Abbott are applicable to some extent and they refer to avoiding marriage with members of another faith, nationality, or ethnic group.

\section{Conclusion}

Macedonian contemporary society is multicultural and dynamic. The visibility of social and family diversity is further enhanced by the development of digital technology and access to information. However, three decades after its independence and two decades after the 2001 armed conflict, North Macedonia still faces some difficulties in implementing the concept of civil society. There is a general improvement in interethnic communication, tolerance in everyday life, and acceptance of different cultures, however, religious and ethnic differences continue to be visible in the public sphere and emphasized by political and spiritual leaders. As a consequence, the rate of intercultural marriages in our country is relatively small, and mixed marriages are generally conducted between partners belonging to ethnic groups of the same faith. This is confirmed by the latest available data from the State Statistical Office, as well as our qualitative research according to which there are still prejudices about mixed marriages, as well as pressure from parents or the community.

In general, mixed marriages in North Macedonia are conducted between partners from ethnic communities that share the same faith and tradition, i.e. between Macedonians and Serbs and Albanians and Turks, which indicates that the Macedonian contemporary society is still divided into religious and ethnic lines. In this context, we could not find a correlation between the language factor and intercultural marriages and we believe that this should be deepened in further research. Finally, given that the Macedonian and Albanian ethnic groups are the most numerous, the number of marriages between these two communities is not negligible. Therefore, we believe that it is necessary to do separate research on mixed marriages that would focus more specifically on these two ethnic communities.

\section{Bibliography}

Авировиќ Бундалевска, И. (2020). “Структурни промени на семејството: перцепции за нови модели на семејни заедници во Република Северна Македонија". Годишен Зборник, бр.73, Скопје: Филозофски факултет. стр. 449-460.

Avirovic Bundalevska, I. Dragovic, I. (2020). "Implementation of the Ohrid Framework Agreement: Trends in Tolerance among Youth in the Republic of North Macedonia". Religious Dialogue and Cooperation, Vol.1, no.1. Skopje: Faculty of Philosophy, стр. 11-27. 
Abela, A. and Walker, J., ed. (2014). Contemporary Issues in Family Studies Global Perspectives on Partnerships, Parenting and Support in a Changing World, 1st ed. West Sussex: Wiley Blackwell.

Abot, E. (2014). Istorija braka. Beograd: Geopoetika izdavaštvo.

Aldridge, Delores P. (1978). "Interracial Marriages: Empirical and Theoretical Considerations." Journal of Black Studies, vol. 8, no. 3. pp. 355-368. JSTOR, www.jstor.org/stable/2783649 (01.06.2021).

Државен завод за статистика на Република Северна Македонија. Склучени бракови според припадноста кон етничка заедница на невестата и на младоженецот, по години. Мак-стат база на податоци. Преземено од: httр://makstat.stat.gov.mk/ (01.06.2021).

Danika, N., Hiew, W., Kim Halford. and Shuang Liu. (2014). “Loving Diversity Living in Intercultural Couple Relationships". In: A. Abela and J. Walker, ed., Contemporary Issues in Family Studies Global Perspectives on Partnerships, Parenting and Support in a Changing World, 1st ed. West Sussex: Wiley Blackwell.

Hannemann, Tina, et al. (2018). “Co-Ethnic Marriage versus Intermarriage among Immigrants and Their Descendants: A Comparison across Seven European Countries Using Event-History Analysis." Demographic Research, vol. 39, pp. 487-524. JSTOR, www.jstor.org/stable/26585338 (01.06.2021).

Magosci, P.R. (1995). Historical Atlas of East Central Europe, University of Toronto Press.

Glenny, M. (2001). The Balkans, Nationalism, War, and the Great Powers, 18041999. London: Penguin Books.

Somer, M. (2001). "Cascades of Ethnic Polarization: Lessons from Yugoslavia." The Annals of the American Academy of Political and Social Science, vol. 573, pp. 127-151. JSTOR, www.jstor.org/stable/1049018 (01.06.2021).

Smits, J. (2010). “Ethnic Intermarriage and Social Cohesion. What Can We Learn from Yugoslavia?" Social Indicators Research, 96( 3), 417-432. http://www. jstor.org/stable/40649328 (01.06.2021).

Стојаноски, Н. (1995). “Етничко-традиционалните и религиски дистинктните културни обрасци како фактор на семејна (дез)интеграција”.

Социолошка ревија, бр.1 год. 1. Скопје: Филозофски факултет. стр. 154-164. Достапно на: http://periodica.fzf.ukim.edu.mk/socr/SOCR\%20 1995.1/SOCR\%201995.1.16.\%20Stojanoski,\%20N.\%20-\%20Etnickoradicionalnite\%20i\%20religiski\%20distinktnite\%20kulturni\%20obrasci.pdf (20.05.2021) 